\title{
Population divergence in the chloroplast genome of Eucalyptus nitens
}

\author{
M. BYRNE* \& G. F. MORAN \\ Division of Forestry, CSIRO, PO BOX 4008, Queen Victoria Terrace, Canberra, ACT 2600, Australia
}

\begin{abstract}
Variation in the chloroplast genome of Eucalyptus nitens was assessed for ten individuals from each of eight populations covering the natural range of the species. Twienty-five mutations were detected which were distributed over 13 haplotypes. The mutations were present both within and between populations. The level of nucleotide diversity within the species was high and the majority of the variation was distributed between populations and regions. The level and distribution of haplotype diversity were similar to those of the nucleotide diversity. The interpopulational variation may be related to the large range and disjunct populations that characterize the species, due to the effects of isolation and genetic drift. There were three mutations which were unique and fixed in one small population. Individuals in the species could be distinguished into two cpDNA groups. The distribution of these groups was not consistent with any geographical pattern. The distribution of the cpDNA groups suggests that they are of ancient origin and predate the isolation of the regions. The pattern of cpDNA variation is not consistent with patterns of variation in morphological traits.
\end{abstract}

Keywords: cpDNA, eucalypts, evolution, genetic diversity.

\section{Introduction}

The chloroplast $(c p)$ genome is highly conserved and has a lower mutation rate than plant nuclear genomes (Wolfe et al., 1987). Certain characteristics of the $c p$ genome, such as uniparental inheritance, the lack of recombination and repeated sequences, reduce the level of variation compared with the nuclear genome which does not have these characteristics (Birky, 1988). These characteristics of the $c p$ genome also led to the expectation that the level of diversity within species would be very low. This view was supported by the first large-scale intraspecific survey of cpDNA diversity - a study of 100 individuals of Lupinus texensis which reported low levels of diversity with only three polymorphisms being detected (Banks \& Birky, 1985). Since then several reports of intraspecific variation in the $c p$ genome have appeared even though the detection of such variation was not the aim of these investigations and the methods used were not optimal for detecting such variation. Soltis et al. (1992b) have reviewed the reports and found examples of intraspecific cpDNA variation in 60 species.

Studies of variation in the $c p$ genome within and between populations have been carried out in a number of species (reviewed in Soltis et al., 1992b).

\footnotetext{
*Correspondence.
}

These studies have revealed a range of level of variation from no variation in Pennisetum glaucum (Clegg et al., 1984; Gepts \& Clegg, 1989) to extensive variation both within and between populations in Trifolium pratense (Milligan, 1991). For a number of species there has been sufficient variation within the species to undertake some intraspecific phylogeography (Soltis et al., 1989b, 1991, 1992a) in a similar way to that in which variation in the mitochondrial genome in some animal species has been used to investigate the evolutionary forces at the population level (Avise et al., 1987).

Analysis of the distribution of cpDNA variation in species has shown that in general the majority of the variation appears between populations with low levels of intrapopulational variation (Soltis et al., 1989b, 1991; Kim et al., 1992). The characteristics of the $c p$ genome that reduce variation compared with the nuclear genome would also tend to increase the level of differentiation between populations. This would have a greater effect in species with geographically isolated populations and populations of small size.

The genus Eucalyptus is a large and important one within the family Myrtaceae, comprised primarily of species native to Australia. The $c p$ genome in eucalypts is maternally inherited and has the typical structure of angiosperm cpDNA with a large inverted repeat separating a small single copy and a large single copy region (Byrne et al., 1993). Heterologous cpDNA 
clones from petunia (Sytsma \& Gottlieb, 1986) and tobacco (Suguira et al., 1986; Shinozaki et al., 1986) cover the entire $c p$ genome in a known order and therefore can be used as heterologous probes to survey cpDNA in eucalypts.

The species Eucalyptus nitens (Deane \& Maiden) Maiden has a wide natural distribution in eastern Australia ranging from northern New South Wales to central Victoria (Pederick, 1979) but has highly disjunct populations. There are four recognized regions in the species distribution: northern New South Wales, southern New South Wales, Errinundra and central Victoria. The morphology of the species has been studied extensively (Pederick, 1979; Cook \& Ladiges, 1991) and there is considerable variation for a range of characters. The species also shows considerable genetic diversity at the population level for isozymes (G. F. Moran, unpublished data) and some variation in polyphenolic constituents (Pederick \& Lennox, 1979).

This study investigates the diversity of cpDNA within the species $E$. nitens. Restriction fragment length polymorphism across the $c p$ genome was determined for ten individuals from each of eight populations covering the natural range of the species in south-eastern Australia.

\section{Materials and methods}

\section{Plant collections}

Mature leaves were collected from ten individuals from each of eight populations (Fig. 1). Two populations were collected from each of the four recognized regions within the species distribution, Ebor and Barrington from northern New South Wales (NN), Tallaganda and Glen Bog from southern New South Wales (SN), Errinundra and Cottonwood from the Errinundra Plateau (ER) and Macalister and Rubicon from central Victoria (CV). Samples from the Ebor, Barrington, Tallaganda, Errinundra and Cottonwood populations were collected from natural stands. Samples from the Glen Bog, Macalister and Rubicon populations were collected from a field trial near Burnie (North Forest Products, Tasmania).

\section{DNA procedures}

Total genomic DNA was extracted from $10 \mathrm{~g}$ of leaves as described in Byrne et al. (1993). Restriction digestion and hybridization were as previously described (Byrne et al., 1993). For each individual sample $5 \mu \mathrm{g}$

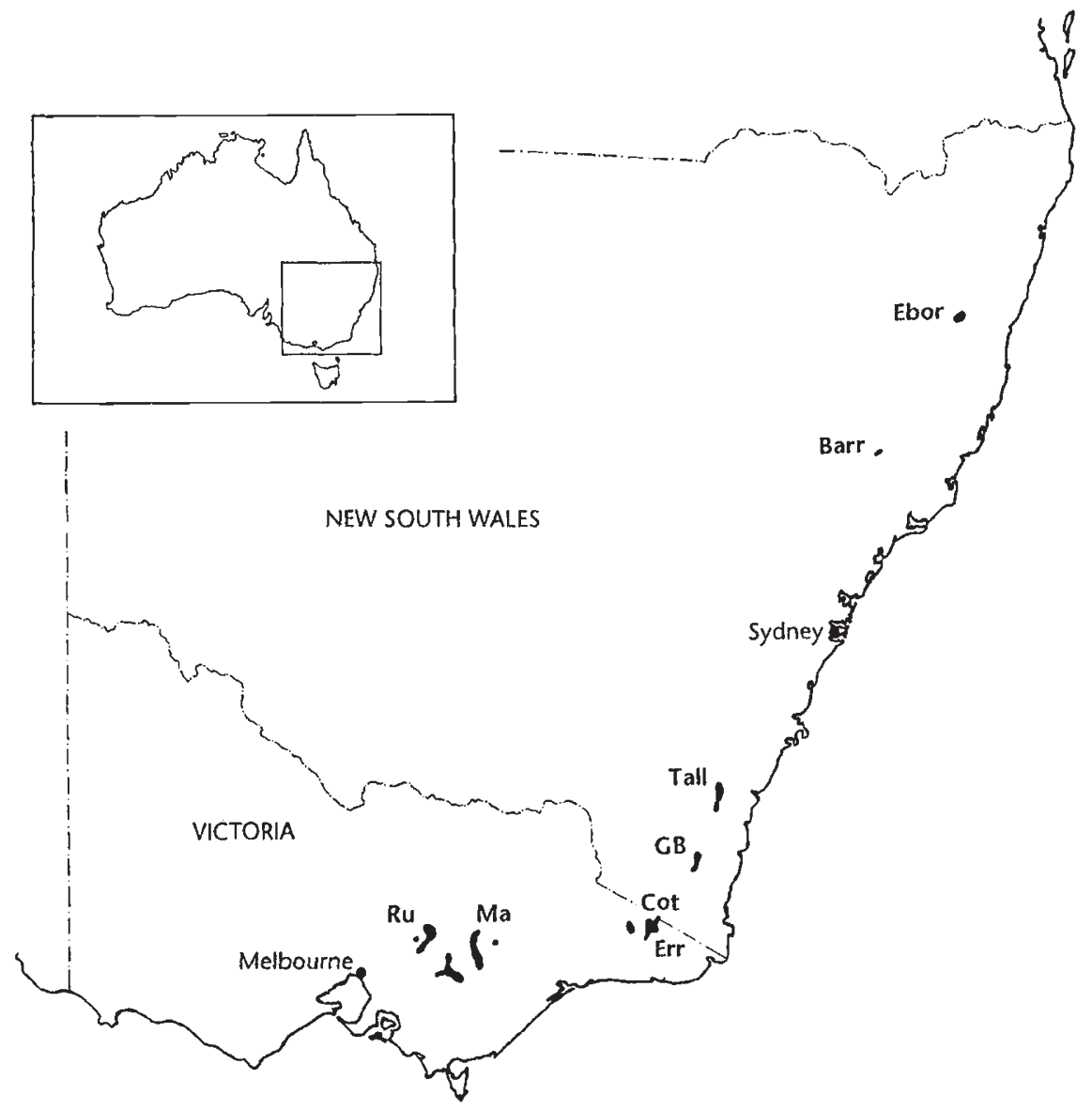

Fig. 1 Natural distribution of E. nitens and location of sampled populations. Ebor, Ebor; Barr, Barrington Tops; Tall, Tallaganda; GB, Glen Bog; Cot, Cottonwood Ridge; Err, Errinundra; Ma, Macalister; Ru, Rubicon. 
DNA was digested with various enzymes and hybridized with heterologous probes covering the entire $c p$ genome. Nine petunia cpDNA probes were used (P1, P3, P4, P6, P8, P12, P14, P19, P20) (details given in Sytsma \& Gottlieb, 1986) plus four tobacco cpDNA probes (pTBa1, pTB13, pTB25, pTB28) (Suguira et al., 1986; Shinozaki et al., 1986) to span the regions not covered by the available petunia probes. Probes were prepared for use in hybridizations by excision of DNA inserts with an appropriate restriction enzyme, then, following gel electrophoresis in low melting point agarose, the insert DNA was cut out, the agarose melted in the presence of $20 \mathrm{~mm}$ Tris, $1 \mathrm{~mm}$ EDTA, organically extracted with phenol then phenol/chloroform and the DNA precipitated with ethanol. Probes were labelled with ${ }^{32} \mathrm{P}$ to high specific activity using the random priming method.

\section{Population survey}

In an initial survey, one individual from each population was screened with 20 restriction enzymes (ApaI, $B a m \mathrm{HI}, B c l \mathrm{I}, B g l \mathrm{II}, B s m \mathrm{I}, D r a \mathrm{I}$, EcoRI, EcoRV, EcoT221, HaeIII, HhaI, HindIII, MspI, PstI, SacI, SalI, ScaI, TaqI, XbaI, XhoI) for each cpDNA probe. Those enzymes that revealed polymorphism between the populations were then used in a full survey to screen all ten individuals from each population for each cpDNA probe.

\section{Data analysis}

Since the whole of the genome was screened, all fragments and restriction sites were analysed for each enzyme. Fragment patterns for consecutive probes were compared to ensure that each polymorphism was correctly interpreted and only counted once. On several occasions a restriction site mutation initially appeared to be a length mutation until analysis of the fragment pattern of the next consecutive probe around the genome.

Nucleotide diversity was calculated for restriction site mutations using HAPLO (Lynch \& Crease, 1990). Nucleotide diversity was calculated at the species level and between and within populations. Haplotype diversity was calculated considering haplotypes as alleles at one locus using Nei's gene diversity measures (Nei, 1977). Nei's unbiased genetic distance (Nei, 1978) was calculated using Biosys (Swofford \& Selander, 1981). Biosys was run using each restriction site or length mutation as a locus with two alleles (two fragment lengths or presence/absence of a restriction site). An UPGMA analysis was carried out using genetic distance estimates. A phylogenetic analysis of haplotypes characterized by presence or absence of each mutation was carried out using PAuP (Swofford, 1984), and using all mutations.

\section{Results}

\section{Polymorphism}

The initial survey with 20 restriction enzymes analysed 456 restriction sites which represent 1.8 per cent of the chloroplast genome. This survey revealed polymorphism between populations with eleven restriction enzymes (BamHI, Bcll, BglII, DraI, EcoRI, EcoRV, EcoT221, HhaI, HindIII, SacI, XbaI).

The survey of all individuals with the 11 polymorphic restriction enzymes detected 321 fragments which represents 1.23 per cent of the chloroplast genome. Twenty-five polymorphisms were detected in this survey (Table 1). Fifteen polymorphisms were restriction site mutations and 10 polymorphisms were length mutations. All of the restriction site mutations occurred within the large single copy region. Four length mutations also occurred in the large single copy region, four occurred at the junction of the large single copy region and the inverted repeat and two were observed in the inverted repeat. Thus the polymorphisms were not distributed uniformly throughout the $c p$ genome.

The numbers of restriction site mutations revealed by each enzyme were not the same. Of the eight enzymes that revealed site mutations DraI revealed four mutations, HhaI revealed three mutations, $B g l \mathrm{II}$ and $B c l \mathrm{I}$ revealed two mutations whilst the others (EcoRV, HindIII, SacI and $X b a I$ ) revealed one each. The length mutations, by their nature, were often detected with several restriction enzymes, therefore similar information for length mutations cannot be described.

The 15 restriction site mutations were distributed over 10 haplotypes. The most common haplotype was present in 20 of the 80 individuals and occurred in the central Victorian region. When both restriction site and length mutations were considered there were 13 haplotypes represented with the most common haplotype present in 15 individuals from the central Victorian region. The frequencies of haplotypes and their distributions among populations are presented in Table 2. Polymorphism was observed both within and between populations. Polymorphism was observed between all populations and was observed within all populations except Ebor and Cottonwood. Table 3 shows the frequency of each haplotype in each population. No more than three haplotypes were present in any one population. 
Table 1 Polymorphisms detected in the $c p$ genome

\begin{tabular}{|c|c|c|c|}
\hline $\begin{array}{l}\text { Probe-enzyme } \\
\text { combination }\end{array}$ & $\begin{array}{l}\text { Mutation } \\
\text { type }\end{array}$ & $\begin{array}{l}\text { Fragment } \\
\text { sizes }(k b)\end{array}$ & Individuals \\
\hline 1. P6-HindIII & Site & 13.3 vs. $10.5+2.8$ & Barr 1-10 \\
\hline 2. $\mathrm{P} 3-B c l \mathrm{I}$ & Site & 3.8 vs. $2.1+1.7$ & Barr 1-10 \\
\hline 3. P3-HhaI & Site & 3.35 vs. $1.3+2.05$ & Ebor $1-10$ \\
\hline 4. $\mathrm{P} 3 / \mathrm{pTB} 1-S a c I$ & Site & $8.3+4.2$ vs. 12.5 & Barr 1-10 \\
\hline 5. P8-DraI & Site & 2.3 vs. $1.33+0.97$ & GB $2,7,10$ \\
\hline 6. $\mathrm{pTBa} 1-B g / I I$ & Site & $5.4+4.0$ vs. 9.4 & Tall $1-4,7-10$, GB $1,3-6,8,9$ \\
\hline 7. $\mathrm{P} 6 / \mathrm{P} 8-B g l I I$ & Site & 8.0 vs. $5.1+2.9$ & Tall 5,6 \\
\hline 8. pTBa1-XbaI & Site & $6.8+2.9$ vs. 9.7 & GB 2, 10 \\
\hline 9. P3-DraI & Site & $3.6+6.2$ vs. 9.8 & GB $2,7,10$ \\
\hline 10. $\mathrm{P} 3 / \mathrm{P} 16-B c l 1$ & Site & $5.5+2.1$ vs. 7.6 & Err $4,9,10$ \\
\hline 11. P6-DraI & Site & 12.7 vs. $11.0+1.7$ & Ebor $1-10$, Err $1-3,5-8$, Cot $1-10$ \\
\hline 12. $\mathrm{P} 3-E c o \mathrm{RV}$ & Site & 6.7 vs. $2.9+3.8$ & $\begin{array}{l}\text { Ebor } 1-10, \text { Barr } 1-10, \text { Tall } 5,6, \\
\text { Err } 1-3,5-8, \text { Cot } 1-10\end{array}$ \\
\hline 13. pTB28-HhaI & Site & $7.8+1.6$ vs. 9.4 & Tall 2,4 \\
\hline 14. P19/pTB28-HhaI & Site & 5.6 vs. $3.3+2.3$ & Tall 5,6 \\
\hline 15. P19/pTB28-DraI & Site & 15.1 vs. $12.0+3.1$ & $\begin{array}{l}\text { Ebor } 1-10, \text { Tall } 5,6, \\
\text { Err } 1-3,5-8, \text { Cot } 1-10\end{array}$ \\
\hline 16. P6-BglII & Length & 1.8 vs. 0.69 & Err $1-3,5-8$, Cot $1-10$ \\
\hline 17. P8-DraI & Length & 1.15 vs. 1.02 & Err $2,3,5$ \\
\hline 18. P3-DraI & Length & 0.72 vs. 1.1 & Ma $1-4,6,8$, Ru $1,4-10$ \\
\hline 19. P19-EcoRV & Length & 2.05 vs. 0.95 & $\begin{array}{l}\text { Ebor } 1-10, \text { Barr } 1-10, \text { Tall } 5,6 \text {, } \\
\text { Err } 1-3,5-8, \text { Cot } 1-10\end{array}$ \\
\hline 20. P19/P12-BglII & Length & 3.2 vs. 3.3 & Tall 5,6 \\
\hline 21. P12-BamHI & Length & 1.28 vs. 1.18 & $\begin{array}{l}\text { Ebor } 1-10, \text { Barr } 1-10, \text { Tall } 5,6 \text {, } \\
\text { Err } 1-3,5-8, \text { Cot } 1-10\end{array}$ \\
\hline 22. $\mathrm{P} 19-X b a \mathrm{I}$ & Length & 1.66 vs. 3.4 & Barr 8 \\
\hline 23. pTB28-BamHI & Length & 1.25 vs. 0.96 & $\begin{array}{l}\text { Ebor } 1-10, \text { Barr } 1-10 \text {, Tall } 5,6 \text {, } \\
\text { Err } 1-3,5-8, \text { Cot } 1-10\end{array}$ \\
\hline 24. P14-DraI & Length & 20.5 vs. 19.3 & $\begin{array}{l}\text { Tall } 1-4,7-10, \text { GB } 1,3-6,8-9, \\
\text { Err } 4,9-10, \text { Ma } 1-10, \text { Ru } 1-10\end{array}$ \\
\hline 25. P19-HindIII & Length & 6.2 vs. 7.0 & GB $2,7,10$ \\
\hline
\end{tabular}

For length mutations only one enzyme showing the polymorphism is listed. The individuals listed have the fragment sizes listed second.

\section{Nucleotide diversity}

Nucleotide diversity is the average number of nucleotide differences per site between two sequences (Nei, 1978), hence this parameter can be determined for restriction site mutations but not length mutations. Calculations based on the 20 enzymes used in the initial survey of one individual from each population, gave a nucleotide diversity between all pairs of individuals ranging from 0.000 to 0.119 per cent with a mean of 0.064 per cent. However, this is likely to be an underestimate as it is assumed that the nine enzymes that detected no interpopulational variation would not detect any variation within populations. This assumption is probably not valid because a substantial amount of intrapopulational variation was detected in this species. For the 11 enzymes used in the full survey 15 polymorphisms were detected in the initial survey but a further 10 polymorphisms were detected in the full survey. If just the 11 enzymes used to survey all individuals are used, the nucleotide diversity ranged from 0.000 to 0.213 per cent and the mean was 0.084 per cent. Thus the true estimate of nucleotide diversity lies between the two values of 0.064 per cent and 0.084 per cent.

This level of nucleotide diversity is similar to that obtained for a number of other species: Heuchera micrantha: 0.074 per cent (Soltis et al., 1989a), Heuchera grossularifolia: 0.071 per cent (Wolf et al., 1990) and Tolmiea menziesii: 0.076 per cent (Soltis et al., 1989b). All of these species have diploid and tetraploid races which may raise the level of diversity com- 
Table 2 Frequency of haplotypes and distribution among individuals for $(a)$ restriction site mutations and $(b)$ restriction site and length mutations

\begin{tabular}{|c|c|c|c|}
\hline Haplotype & \multirow{2}{*}{$\frac{\text { Frequency }(\%)}{25.0}$} & \multirow{2}{*}{$\begin{array}{l}\text { Individuals } \\
\text { Ma } 1-10, \text { Ru 1-10 }\end{array}$} & \multirow[t]{2}{*}{ Mutations } \\
\hline (a) & & & \\
\hline 2 & 3.75 & Err $4,9,10$ & 10 \\
\hline 3 & 2.50 & Tall 5,6 & $7,12,14,15$ \\
\hline 4 & 21.25 & Err $1-3,5-8$, Cot $1-10$ & $11,12,15$ \\
\hline 5 & 1.25 & GB 7 & 5,9 \\
\hline 6 & 2.50 & GB 2, 10 & $5,8,9$ \\
\hline 7 & 12.50 & Barr $1-10$ & $1,2,4,12$ \\
\hline 8 & 12.50 & Ebor $1-10$ & $3,11,12,15$ \\
\hline 9 & 2.5 & Tall 2,4 & 6,13 \\
\hline 10 & 16.25 & Tall $1,3,7-10$, GB $1,3-6,8,9$ & 6 \\
\hline \multirow[t]{13}{*}{ (b) } & 12.50 & Ebor $1-10$ & $3,11,12,15,19,21,23$ \\
\hline & 11.25 & Barr $1-7,9,10$ & $1,2,4,12,19,21,23$ \\
\hline & 1.25 & Barr 8 & $1,2,4,12,19,21,22,23$ \\
\hline & 6.25 & Ma 5,9,10, Ru 2, 3 & 24 \\
\hline & 2.50 & Tall 5,6 & $7,12,14,15,19,20,21,23$ \\
\hline & 2.50 & GB 2, 10 & $5,8,9,25$ \\
\hline & 1.25 & GB 7 & $5,9,25$ \\
\hline & 17.50 & Err $1,6-8, \operatorname{Cot} 1-10$ & $11,12,15,16,19,21,23$ \\
\hline & 3.75 & $\operatorname{Err} 4,9,10$ & 10,24 \\
\hline & 3.75 & Err $2,3,5$ & $11,12,15,16,17,19,21,23$ \\
\hline & 18.75 & Ma $1-4,6-8$, Ru $1,4-10$ & 18,24 \\
\hline & 2.5 & Tall 2,4 & $6,13,24$ \\
\hline & 16.25 & Tall $1,3,7-10$, GB $1,3-6,8,9$ & 6,24 \\
\hline
\end{tabular}

Mutation numbers are as in Table 1.

pared with species with no polyploidy. An estimate of nucleotide diversity in only the diploid members of Tolmiea menziesii was a little lower than for the species as a whole at 0.064 per cent. However, these values are the highest reported to date and are high in comparison with those of some other species: e.g. Lupinus texensis: 0.026 per cent (Banks \& Birky, 1985) and Pennisetum glaucum: 0 per cent (Gepts \& Clegg, 1989).

Analysis of the distribution of diversity was carried out for both the initial 20 enzymes and the 11 enzymes used in the full survey. The pattern of distribution of diversity was very similar for both data sets and only values for one will be given, using all 20 enzymes. The use of all 20 enzymes may slightly underestimate the variation within populations as it assumes that the nine enzymes not used in the full survey were invariant within populations as well as between populations. The mean nucleotide diversity within populations was 0.016 per cent and between populations was 0.056 per cent. The proportion of diversity maintained between populations, $N_{\mathrm{ST}}$, was 78.2 per cent for the species as a whole. This value is extremely high and means that most of the diversity in the species is maintained between rather than within populations. $N_{\mathrm{ST}}$ has not been calcu- lated for $c p$ genomes of other plant species and therefore no comparison can be made. Between regions the $N_{\text {ST }}$ value was 55.5 per cent which is more than twothirds of the proportion of diversity between populations of the whole species. Within regions $N_{\mathrm{ST}}$ was generally low $(0-20$ per cent $)$ except for northern New South Wales which showed little variation within populations but distinct variation between populations (Table 4).

\section{Haplotype diversity}

The distribution of haplotype diversity within and between populations can be determined by treating the whole $c p$ genome as a single locus with each haplotype as an allele. In this way the haplotype diversity within and between populations for the species as a whole was calculated for restriction site mutations and length mutations separately and for all mutations combined (Table 5). The proportion of diversity maintained between populations, $G_{\mathrm{ST}}^{\prime}$, within the species for restriction site mutations was 78.4 per cent, which is very similar to the proportion of nucleotide diversity maintained between populations $\left(N_{\mathrm{ST}}=78.2\right.$ per cent $)$. 
This also indicates very high population differentiation for haplotype diversity. For the length mutations alone and all mutations combined the $G_{\mathrm{ST}}^{\prime}$ value was a little lower (66.1 per cent and 62.1 per cent, respectively).

Table 3 Frequency of haplotypes in populations for (a) restriction site mutations and (b) restriction site and length mutations

\begin{tabular}{llllllllll}
\hline Haplotype & Ebor & Barr & Tall & GB & Err & Cot & Ma & Ru \\
\hline (a) & 1 & 0 & 0 & 0 & 0 & 0 & 0 & 1.0 & 1.0 \\
& 2 & 0 & 0 & 0 & 0 & 0.3 & 0 & 0 & 0 \\
& 3 & 0 & 0 & 0.2 & 0 & 0 & 0 & 0 & 0 \\
& 4 & 0 & 0 & 0 & 0 & 0.7 & 1.0 & 0 & 0 \\
5 & 0 & 0 & 0 & 0.1 & 0 & 0 & 0 & 0 \\
& 6 & 0 & 0 & 0 & 0.2 & 0 & 0 & 0 & 0 \\
7 & 0 & 1.0 & 0 & 0 & 0 & 0 & 0 & 0 \\
8 & 1.0 & 0 & 0 & 0 & 0 & 0 & 0 & 0 \\
9 & 0 & 0 & 0.2 & 0 & 0 & 0 & 0 & 0 \\
10 & 0 & 0 & 0.6 & 0.7 & 0 & 0 & 0 & 0 \\
A b) & 1.0 & 0 & 0 & 0 & 0 & 0 & 0 & 0 \\
B & 0 & 0.9 & 0 & 0 & 0 & 0 & 0 & 0 \\
C & 0 & 0.1 & 0 & 0 & 0 & 0 & 0 & 0 \\
D & 0 & 0 & 0 & 0 & 0 & 0 & 0.3 & 0.2 \\
E & 0 & 0 & 0.2 & 0 & 0 & 0 & 0 & 0 \\
F & 0 & 0 & 0 & 0.2 & 0 & 0 & 0 & 0 \\
G & 0 & 0 & 0 & 0.1 & 0 & 0 & 0 & 0 \\
H & 0 & 0 & 0 & 0 & 0.4 & 1.0 & 0 & 0 \\
I & 0 & 0 & 0 & 0 & 0.3 & 0 & 0 & 0 \\
J & 0 & 0 & 0 & 0 & 0.3 & 0 & 0 & 0 \\
K & 0 & 0 & 0 & 0 & 0 & 0 & 0.7 & 0.8 \\
L & 0 & 0 & 0.2 & 0 & 0 & 0 & 0 & 0 \\
M & 0 & 0 & 0.6 & 0.7 & 0 & 0 & 0 & 0 \\
\hline
\end{tabular}

However, these values are still indicative of high population differentiation.

\section{Population relationships}

An UPGMA analysis of all mutations showed two major clusters, namely, one comprising the central Victorian and southern New South Wales regions and a second comprising the Errinundra and northern New South Wales regions (Fig. 2). The four populations from the central Victoria and southern New South Wales regions were very similar to each other and form a closely related group. The two populations from the Errinundra region were most similar to the Ebor population from northern New South Wales. The Barrington population from northern New South Wales was grouped in the cluster with the Errinundra region and the Ebor population but was the most distinct of all the populations. Analysis using only restriction site mutations gave the same pattern, except for the Barrington

Table 5 Distribution of haplotype diversity within and between populations for each mutation type

\begin{tabular}{llll}
\hline & \multicolumn{1}{c}{$H_{\mathrm{S}}$} & \multicolumn{1}{c}{$D_{\mathrm{ST}}^{\prime}$} & $G_{\mathrm{ST}}^{\prime}(\%)$ \\
\hline $\begin{array}{l}\text { Restriction site } \\
\text { mutations }\end{array}$ & 0.18 & 0.68125 & 78.4 \\
$\begin{array}{l}\text { Length mutations } \\
\text { All mutations }\end{array}$ & 0.2675 & 0.52125 & 66.1 \\
\hline
\end{tabular}

$H_{\mathrm{S}}$ : variation within populations: $D_{\mathrm{S} T}^{\prime}$ : variation between populations; $G_{\mathrm{ST}}^{\prime}$ : proportion of total variation between populations.

Table 4 Distribution of nucleotide diversity within and between populations and regions

\begin{tabular}{|c|c|c|c|}
\hline & $V_{\mathrm{w}}$ & $V_{\mathrm{b}}$ & $N_{\mathrm{ST}}(\%)$ \\
\hline $\begin{array}{l}\text { Populations } \\
\text { within species }\end{array}$ & $0.00016(0.00007)$ & $0.00056(0.00036)$ & $78.2(0.127)$ \\
\hline $\begin{array}{l}\text { Regions } \\
\quad \text { within species }\end{array}$ & $0.00033(0.00010)$ & $0.00041(0.00039)$ & $55.5(0.246)$ \\
\hline $\begin{array}{cc}\text { Populations } & \text { NN } \\
\text { within } & \text { SN } \\
\text { regions } & \text { ER } \\
& \text { CV }\end{array}$ & $\begin{array}{c}0(0) \\
0.00044(0.00016) \\
0.00019(0.00005) \\
0(0)\end{array}$ & $\begin{array}{c}0.00119(0.00049) \\
0.00005(0.00019) \\
0.00005(0.00020) \\
0(0)\end{array}$ & $\begin{array}{l}100 \\
10.2 \\
20.8 \\
0\end{array}$ \\
\hline
\end{tabular}

Standard errors are in parentheses.

$V_{\mathrm{w}}$ : variation within; $V_{\mathrm{h}}$ : variation between; $N_{\mathrm{ST}}$ : proportion of variation between; NN, northern New South Wales; SN, southern New South Wales; ER, Errinundra; $\mathrm{CV}$, central Victoria. 


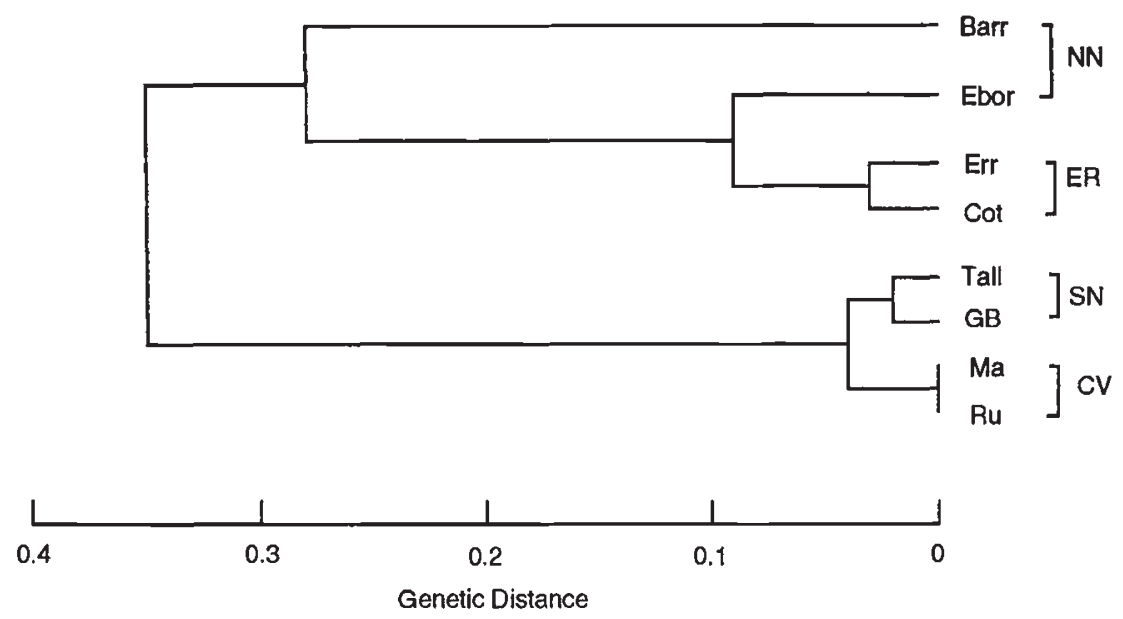

Fig. 2 UPGMA analysis of population relationships based on Nei's genetic distance using all mutations. Population abbreviations as in Fig. 1. NN, northern New South Wales region; SN, southern New South Wales region; ER, Errinundra region; $\mathrm{CV}$, central Victoria region. population which was placed outside the two clusters and clearly separated from these populations.

Some of the cpDNA mutations were specific to populations, i.e. they were present in all individuals sampled from the population and were not present in any individuals from any other population. Three mutations were specific to the Barrington population and one mutation was specific to the Ebor population. Thus two of these polymorphisms can be used to discriminate the Ebor and Barrington populations from each other and from all other populations, and can be used to identify individuals from the northern New South Wales region from those of all other regions. All of these population-specific polymorphisms were restriction site mutations.

\section{Evolutionary relationships of haplotypes}

A phylogenetic analysis of haplotypes based on all mutations gave 615 trees all of length 25.0 with a consistency index of 1.000 . These trees are all essentially the same except for a trifurcation and the rearrangement of five haplotypes that differ from each other by only one mutation each. Since there were no data for an outgroup the analysis was rooted at the midpoint of the longest branch. Figure 3 shows the tree with the trifurcation and one of the arrangements of the five similar haplotypes. The phylogenetic tree shows a network of closely related haplotypes present in two main groups. One of these groups involved Ebor, Barrington, Cottonwood, most of the individuals from Errinundra and two individuals from Tallaganda while the other involved Macalister, Rubicon, Glen Bog, most of the individuals from Tallaganda and three individuals from Errinundra. These groups were separated by four mutations.
The two groups do not represent a simple geographical pattern. Each group is largely comprised of individuals from two regions but in each case these regions are not geographical nearest neighbours. For example, the Errinundra and northern New South Wales regions although grouped into one group are geographically further apart than Errinundra and southern New South Wales. The two groups can also be seen in the UPGMA analysis (Fig. 2). The haplotypes characterizing the Errinundra and Cottonwood populations are most closely related to the haplotype characterizing the Ebor population in the phylogenetic analysis (Fig. 3). These haplotypes are separated by three mutations whilst the haplotypes characterizing the southern New South Wales region and the Errinundra region are separated by nine mutations despite being geographically closer. A small number of individuals possessing the cpDNA pattern characteristic of one group are geographically positioned in the main regions of the other group and vice versa.

\section{Discussion}

Although the level of diversity in the $c p$ genome is generally lower than that of the nuclear genome, the differences between species in total intraspecific diversity in cpDNA are marked. The level of cpDNA diversity ranges from no variation detected (Gepts \& Clegg, 1989) to relatively high levels of variation detected in some species (Soltis et al., 1989a,b; Wolf et al., 1990). The variation detected in E. nitens is at the high end of this range and is similar to that detected in a number of other species. This species has a large geographical range with disjunct populations which may be factors affecting the level 
Fig. 3 Phylogenetic tree of haplotype relationships. Numbers on branches are mutation numbers (see Table 1). Population abbreviations as in Fig. 1, region abbreviations as in Fig. 2.
SN
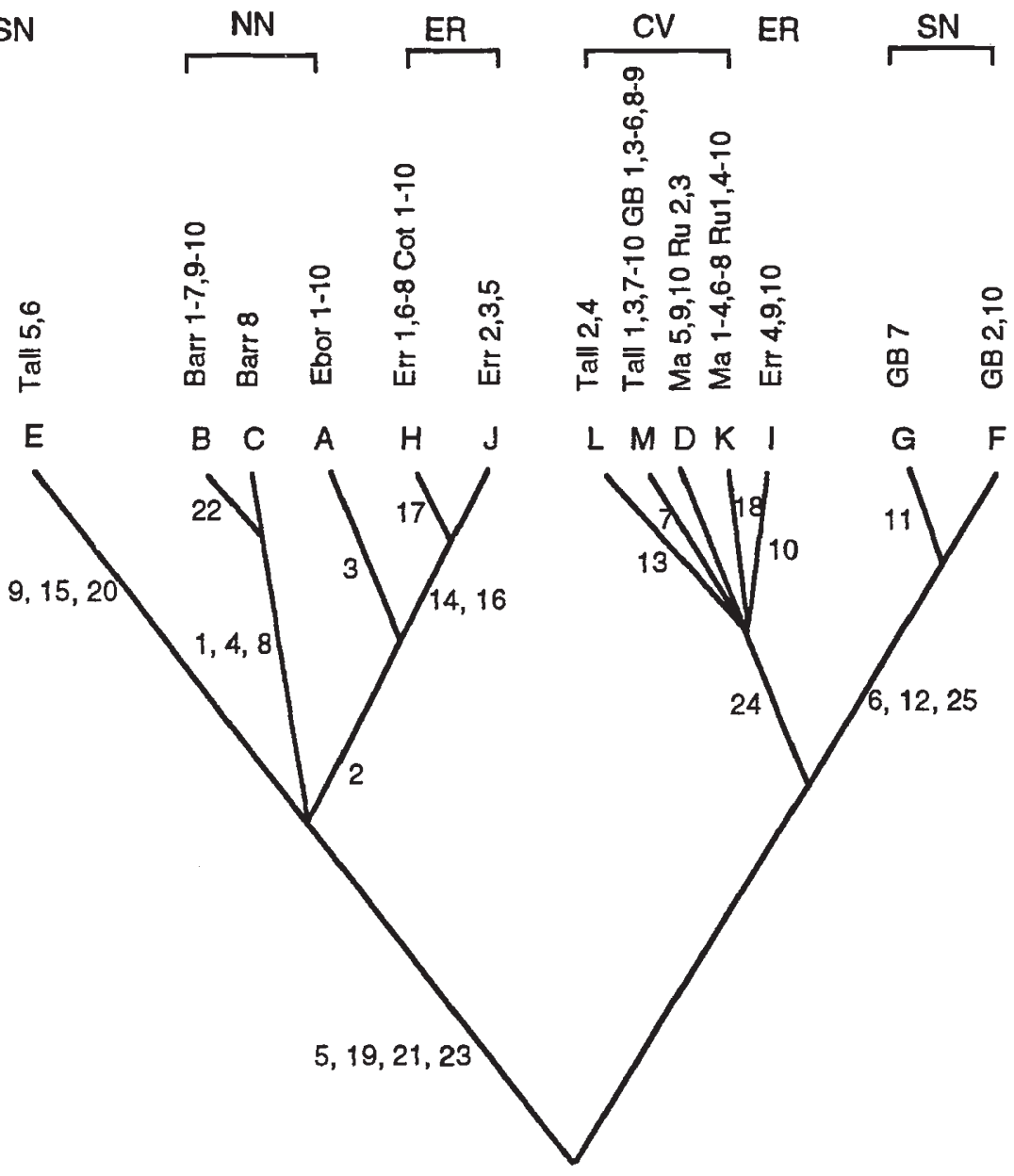

ER

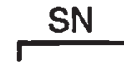

and pattern of diversity maintained in the $c p$ genome. Two other species with high levels of total cpDNA diversity also have large ranges and disjunct isolated populations, Heuchera micrantha (Soltis et al., 1989a) and Tolmiea menziesii (Soltis et al., 1989b). As more information on intraspecific cpDNA diversity is accumulated the effects of certain characteristics and lifehistory traits on the maintenance of diversity within the $c p$ genome may be elucidated in a similar way to the patterns that have emerged for isozyme markers (Hamrick \& Godt, 1990).

Intrapopulational variation was detected in six of the eight populations analysed. This is in contrast to the generally low levels of intrapopulational variation maintained even within species with high levels of total cpDNA diversity. However, despite the cases of intrapopulational variation, the majority of the diversity in the species is found between populations ( $N_{\mathrm{ST}}$ and $G_{\mathrm{ST}}^{\prime}$ both 78 per cent). More than half of the variation is also distributed between regions (56 per cent). This strong regional distribution of the variation is probably related to the large geographical distances that separate the regions and some populations within regions. Due to maternal inheritance of the $c p$ genome, cpDNA gene flow is limited to seed dispersal. There are no active mechanisms or adaptations for seed dispersal in eucalypts and few seed travel further than twice the height of the parent tree (Boland et al., 1980). A combination of geographical separation and limited gene flow also results in extremely limited migration between regions and populations. As the $c p$ genome does not undergo recombination and with very low, if any, migration, the pattern of interpopulational variation in the $c p$ genome reflects the outcomes of mutational input, varying degrees of isolation between populations and fluctuations in population size.

Within most of the regions the populations are reasonably close together except for the northern New South Wales region. The two populations in the NN region are $180 \mathrm{~km}$ apart and perhaps should be considered as two separate regions. The high diversity in this region is shown in the population specific mutations which can be used to distinguish the two populations from each other and from every other population 
in the species. The Barrington population is very small and an estimate of current reproductive individuals lies between 100 and 500. Due to uniparental inheritance the effective population size for the $c p$ genome is half that of the nuclear genome (Birky, 1988). Long-term isolation and small size of the Barrington population means that genetic drift could have had a larger role in determining the fixation of haplotypes in this population. The mutations that uniquely characterize the $c p$ genome in the Barrington population all occur in one area of the large single copy region and are all restriction site mutations. This suggests that this area may be a hotspot for mutational activity in the $c p$ genome or that these mutations confer a selective advantage. The presence of three fixed mutations and the low level of intrapopulational diversity suggests that the Barrington population may well have been through a recent bottleneck. The level of isozyme variation in this population is also consistent with the suggestion of a bottleneck effect (G. F. Moran, unpublished data). The possibility that the differences characterizing the Barrington population may be due to introgression of the $c p$ genome from some other species should also be considered. The most likely species to have contributed a $c p$ genome are E. dalrympleana and E. cypellocarpa, as these species occur in the same area as the Barrington population but at lower altitude. Neither of these two species have been investigated for cpDNA, hence this theory cannot be tested. Although plausible, introgression seems unlikely because the Barrington population possesses the four mutations that characterize the northern New South Wales/Errinundra group. If introgression has occurred then the species donating the $c p$ genome must also have these mutations suggesting that these two groups are not restricted to $E$. nitens but pre-date the speciation of this species and several other species from E. dalrympleana and $E$. cypellocarpa.

The cpDNA relationships between populations within regions are consistent with their geographical position. In our data, populations within regions were more closely related to each other than to any population from another region. However, the cpDNA relationships between regions are more complex and are not correlated with their geographical positions. Both the UPGMA and cladistic analysis put the central Victoria and southern New South Wales regions as one group and northern New South Wales and Errinundra as the other. Neither grouping is consistent with their geographical positions; however, the similarity between northern New South Wales (particularly the Ebor population) and Errinundra is surprising. Ebor is 900 $\mathrm{km}$ north of the Errinundra region and would have been isolated from this area for a long time. The south- ern New South Wales populations are geographically positioned between Ebor and Errinundra yet do not share the mutations present in their group. The groups also do not strictly circumscribe the regions. There are three individuals from the Errinundra population that have the character state of the mutations typical of the central Victoria/southern New South Wales group; and there are two individuals from the Tallaganda population that possess the character states characteristic of the northern New South Wales/Errinundra group. The lack of complete congruence between groups and regions suggests that the two groups were common throughout the whole area before the regions became isolated due to climatic and geological changes. Since the isolation of the regions the frequency of the two groups within regions has changed, with one group becoming predominant in two regions and the other predominant in the remaining regions. This suggests that the mutations characterizing the two groups are of ancient origin. The mutations that result in branching of haplotypes within the two groups are more local in their distribution and may be of more recent origin.

Geographical structuring into regional lineages has been observed in a number of other species for which population surveys have been carried out, Tolmiea menziesii (Soltis et al., 1989b), Tellima grandiflora (Soltis et al., 1991), Tiarella trifoliata (Soltis et al., 1992a) and Gliricidia sepium (Lavin et al., 1991). Three of these species are members of the Saxifragaceae and have similar geographical distributions and life-histories. The geographical structuring of the $c p$ genome of these species has been related to glaciation events. The other species, Gliricidia sepium, is a tropical tree and the two lineages also show morphological and isozyme differences as well as cpDNA variation. However, in all of these cases and in contrast to the situation in $E$. nitens, the structuring of the $c p$ genome has not been inconsistent with their geographical positions or geographical history.

Isozyme (G. F. Moran, unpublished data) and morphological (Cook \& Ladiges, 1991) surveys of E. nitens have shown a high level of diversity with high population differentiation and are consistent with the cpDNA data presented here. The relationships between populations for isozymes, although not entirely the same, are consistent with those of the cpDNA. The central Victoria and southern New South Wales populations cluster together, the northern New South Wales populations are the next most similar group and then the populations from the Errinundra region. However, data on morphological traits are not concordant with the cpDNA data. Some individuals, mainly from the Errinundra region but also some from central Victoria, show some morphological differences from the rest of 
the species. The main character that distinguishes these individuals is the presence of denticulate margins on the leaves (Cook \& Ladiges, 1991). Pederick (1979a) recognized these individuals as a variety of the species, $E$. nitens var. errinundra, with the rest of the species named $E$. nitens var. nitens. Recently the Errinundra variety was described as a new species, $E$. denticulata (Cook \& Ladiges, 1991) based on a survey of morphological variation.

In describing the new species Cook \& Ladiges (1991) proposed that $E$. denticulata and E. quadrangulata were split off from $E$. nitens and that subsequent changes caused a split between $E$. denticulata and $E$. quadrangulata. E. quadrangulata also has denticulate leaf margins; however, it is clearly distinct from the main $E$. nitens and the Errinundra region for isozymes (G. F. Moran, unpublished data). There are no available data from the $c p$ genome for $E$. quadrangulata to enable a full comparison with the morphological data. The cpDNA data presented here indicate that the variation in the populations in the Errinundra region is not distinct from the variation in the species as a whole. This is not consistent with the origins proposed for $E$. denticulata. The close similarity of the $c p$ genome in Ebor and Errinundra suggests that the evolution of the two groups occurred before the geographical isolation of the regions and therefore they may represent ancient lineages. As the $c p$ genome is more highly conserved than the nuclear genome and evolves more slowly, analysis of cpDNA may give a view of the evolutionary relationships of populations at an earlier point in time than do nuclear markers. It may be that the original evolution of the two lineages of cpDNA occurred without a corresponding split in the nuclear genome. Subsequently more rapid evolution of the nuclear genome in the Errinundra region may have occurred giving rise to the morphological differences that characterize this region.

The high level of intraspecific polymorphism found in some species has led to a note of caution in the use of cpDNA in phylogenetic studies (Soltis et al., 1992b). The relatively high level of polymorphism in the $c p$ genome of $E$. nitens dictates that such caution be applied in the use of cpDNA in phylogenetic studies in this species and maybe in eucalypts in general. The distribution of variation, particularly the high level of interpopulation variation suggests that the species should be sampled for several individuals and populations across the range when using cpDNA for phylogenetic studies. Further investigation of cpDNA diversity in other eucalypt species is needed to determine whether the polymorphism in E. nitens is typical of eucalypts in general or particular to this species perhaps due to its large range and disjunct distribution.

\section{Acknowledgements}

The petunia cpDNA clones were kindly provided by J. Palmer. The tobacco cpDNA clones were used with the permission of M. Sugiura. We wish to thank J. Murrell for technical assistance and T. Vercoe, C. Gardiner and J. Morse for assistance with collection of material. We are grateful to North Forest Products for access to material in the provenance trial. We also thank A. H. D. Brown and M. Crisp for helpful comments on the manuscript.

\section{References}

AVISE, J. C., ARNOLD, J., BALL, R. M., BERMINGHAM, E., LAMB, T., NEIGEL, J. E., REEB, C. A. AND SAUNDERS, N. C. 1987. Intraspecific phylogeny: the mitochondrial bridge between population genetics and systematics. Ann. Rev. Ecol. Syst., 18, 489-522.

BANKS, J. A. AND BIRKY, C. W. 1985. Chloroplast DNA diversity is low in a wild plant, Lupinus texensis. Proc. Natl. Acad. Sci. U.S.A., 82, 6950-6954.

BIRKY, C. W. 1988. Evolution and variation in plant chloroplast and mitochondrial genomes. In: Gottlieb, L. D. and Jain, S. K. (eds) Plant Evolutionary Biology, pp. 23-53. Chapman and Hall, New York.

BOLAND, D. J., BROOKER, M. 1. H. AND TURNBULL, J. W. 1980. Eucalyptus Seed. CSIRO, Canberra, Australia.

BYRNE, M., MORAN, G. F. AND TIBBITS, w. 1993. Restriction map and maternal inheritance of chloroplast DNA in Eucalyptus nitens. J. Hered., 84, 218-220.

CLEGG, M. T., RAWSON, J. R. AND THOMAS, K. 1984. Chloroplast DNA variation in pearl millet and related species. Genetics, 106, 449-461.

COOK, I. O. AND LADIGES, P. Y. 1991. Morphological variation within Eucalyptus nitens s. lat and recognition of a new species E. denticulata. Aust. Syst. Bot., 4, 375-390.

GEPTS, P. AND CLEGG, M. T. 1989. Genetic diversity in pearl millet (Pennisetum glaucum (L.) R.Br.) at the DNA sequence level: consequences for genetic conservation. $J$. Hered, 80, 203-208.

HAMRICK, J. L. AND GODT, M. J. W. 1990. Allozyme diversity in plant species. In: Brown, A. D. H., Clegg, M. T., Kahler, A. L. and Weir, B. S., (eds), Plant Population Genetics, Breeding and Genetic Resources, pp. 44-46. Sinauer Associates, Sunderland, MA.

KIM, K. J., JANSEN, R. K. AND TURNER, B. L. 1992. Evolutionary implications of interspecific chloroplast DNA variation in dwarf dandelions (Krigia; Asteraceae). Am. J. Bot., 79, 708-715.

LAVIN, M., MATTHEWS, S. AND HUGHES, C. 1991. Chloroplast DNA variation in Gliricidia sepium (Leguminosae): Intraspecific phylogeny and tokogeny. Am.J. Bot., 78, 1576-1585.

LYNCH, M. AND CREASE, T. J. 1990. The analysis of population survey data on DNA sequence variation. Mol. Biol. Evol., 7, 377-394. 
MiLlıgAN, B. G. 1991. Chloroplast DNA diversity within and among populations of Trifolium pratense. Curr. Genet., 19, 411-416.

NE1, M. 1977. F-statistics and analysis of gene diversity in subdivided populations. Ann. Hum. Genet., 41, 225-233.

NEI, M. 1978. Estimation of average heterozygosity and genetic distance from a small number of individuals. Genetics, 89, 583-590.

PEDERICK, L. A. 1979. Natural variation in shining gum (Eucalyptus nitens). Aust. For. Res., 9, 41-63.

PEDERICK, L. A. AND LENNOX, F. G. 1979. Variation in polyphenolic constituents of Eucalyptus nitens Maiden. Aust. J. Bot., 27, 217-226.

SHINOZAK1, K., OHME. M., TANAKA, M., WAKASUG1, T., HAYASHIUDA, N., MATSUBAYASHI, T., ZAITA, N., CHUNWONGSE, J., OBOKATA, J., YAMAGUCH1-SHINOSAK1, K., OHTO, C., TORAZAWA, K., MENG, B. Y., SUGITA, M., DENO, H., KAMAGASHIRA, T., YAMADA, K., KUSUDA, J., TAKAIWA, F., KATO, A., TOHDOH, N., SHIMADA, H., AND SUGIURA, M. 1986. The complete nucleotide sequence of the tobacco chloroplast genome: its gene organization and expression. EMBO J., 5, 2043-2049.

SOLTIS, D. E., MAYER, M. S., SOLTIS, P. S. AND EDGERTON, M. 1991. Chloroplast DNA variation in Tellima grandiflora (Saxifragaceae). Am. J. Bot., 78, 1379-1390.

SOLTIS, D. E., SOLTIS, P. S., KUZOFF, R. K. AND TUCKER, T. L. 1992a. Geographic structuring of chloroplast DNA genotypes in Tiarella trifoliata (Saxifragaceae). Plant Syst. Evol., 181, 203-216.

SOLTIS, D. E., SOLTIS, P. S. AND MILligAN, B. G. 1992 b. Intraspecific chloroplast DNA variation: systematic and phylogenetic implications. In: Soltis, P. E., Soltis, D. E. and Doyle, J. J. (eds) Molecular Systematics of Plants, pp. 117-150. Chapman and Hall, New York.

SOLTIS, D. E., SOLTIS, P. S. AND NESS, B. D. 1989a. Chloroplast DNA variation and multiple origins of autopolyploidy in Heuchera micrantha (Saxifragaceae). Evolution, 43, $650-656$.

SOlTiS, D. E., SOLTIS, P. S., RANKER, T. A. AND NESS, B. D. 1989 b. Chloroplast DNA variation in a wild plant, Tolmiea menziesii. Genetics, 121, 819-826.

SUGUIRA, M., SHINOZAKI, K., ZAITA, N., KUSUDA, M. AND KUMANO, M. 1986. Clone bank of the tobacco (Nicotiana tabacum) chloroplast genome as a set of overlapping restriction endonuclease fragments: mapping of eleven ribosomal protein genes. Plant Sci., 44, 211-216.

SWOFFORD, D. L. 1984. PAUP. Phylogenetic Analysis Using Parsimony. Illinois Natural History Survey, Champaign, Illinois.

SWOFFORD, D. L. AND SELANDER, R. B. 1981. BIOSYS-1. A Computer Program for the Analysis of Allelic Variation in Genetics. Department of Genetics and Development, University of Illinois at Urbana, Champaign, Urbana.

SYTSMA, K. J. AND GOTTlieb, L. D. 1986. Chloroplast DNA evolution and phylogenetic relationships in Clarkia sect. Peripetasma (Onagraceae). Evolution, 40, 1248-1261.

wolf, P. G., SOLTIS, D. E. AND SOLTIS, P. S. 1990. Chloroplast DNA and allozyme variation in diploid and autotetraploid Heuchera grossulariifolia (Saxifragaceae). Am. J. Bot., 77, 232-244.

WOLFE, K. H., L1, W. H. AND SHARP, P. M. 1987. Rates of nucleotide substitution vary greatly among plant mitochondrial, chloroplast and nuclear DNAs. Proc. Natl. Acad. Sci. U.S.A., 84, 9054-9058. 